PSYCHOLOGY AND THE WORLD OF WORK 
Also by David A. Statt

PSYCHOLOGY: MAKING SENSE

THE CONCISE DICTIONARY OF PSYCHOLOGY

THE CONCISE DICTIONARY OF MANAGEMENT 


\section{PSYCHOLOGY AND THE WORLD OF WORK}

DAVID A. STATT

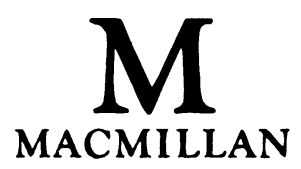


All rights reserved. No reproduction, copy or transmission of this publication may be made without written permission.

No paragraph of this publication may be reproduced, copied or transmitted save with written permission or in accordance with the provisions of the Copyright, Designs and Patents Act 1988, or under the terms of any licence permitting limited copying issued by the Copyright Licensing Agency, 90 Tottenham Court Road, London W1P 9HE.

Any person who does any unauthorized act in relation to this publication may be liable to criminal prosecution and civil claims for damages.

First published 1994 by

THE MACMILLAN PRESS LTD

Houndmills, Basingstoke, Hampshire RG21 2XS

and London

Companies and representatives

throughout the world

ISBN 978-0-333-58461-3

DOI 10.1007/978-1-349-23652-7

ISBN 978-1-349-23652-7 (eBook)

A catalogue record for this book is available from the British Library.

Copy-edited and typeset by Povey-Edmondson

Okehampton and Rochdale, England 


\section{To Bert Cooper}

who taught me most about the meaning of work 


\section{Contents}

List of Figures $\quad$ xi

List of Tables xiii

Preface $\mathrm{xv}$

Acknowledgements $\quad \mathrm{xvi}$

PART I THE ORIGINS OF THE WORLD OF WORK 1

1 Out of the nineteenth century 3

The world of work before psychology 3

The Industrial Revolution and the modern world 8

Scientific psychology and the modern world 13

\section{PART II THE WORKPLACE SETTING 23}

2 Organizations 25

What exactly is an organization? 25

Types of organization 27

Organising rather than organization 29

Conflicts of interest 31

Power and political behaviour 32

Communicating and the use of information 36

Organizational culture(s) $\quad 37$

The psychological contract 38

3 The work environment 41

The senses 41

Ergonomics/human factors 56 
4 The time dimension 63

What do we mean by change? 63

The interacting layers of time 64

The psychology of time 68

5 Work and mental health 84

Health and sickness at work: learning from the Mad Hatter 84

Health and mental health 85

Stress $\quad 88$

6 The 'unconscious' at work 103

The physiological unconscious 103

The dynamic unconscious 104

Using the unconscious in selecting staff $\quad 106$

Personality tests 106

Why you can't hire 'hands' 108

How organizations can split personalities 111

'Self' defence 113

How we collude with our organizations 116

Interpersonal relationships at work 117

Transactional Analysis 118

The neurotic organization 120

The unconscious barriers to change 121

7 Group dynamics and working-group relationships

The importance of groups 124

Unintended influence 125

Intended influence 127

Intragroup relations 133

Intergroup relations 137

Working-group relationships 140

8 Work, non-work and in-between 144

Unemployment 148

Psychological effects of unemployment 153

The individual experience of unemployment 159

Retirement 163

PART III THE INDIVIDUAL'S WORKING LIFE

9 Personality factors 167

Formal theories of personality 168

The Psychoanalytic approach 170

The Behaviourist approach $\quad 173$ 
Humanism 176

Trait theory 178

Informal theories of personality 181

Socialization 184

10 Measuring human abilities 198

Testing 198

Measurement of interests 208

Tests of specific aptitudes and abilities $\quad 210$

11 Recruitment and selection 216

The use of human resources 216

The process of recruitment and selection 216

12 Learning, training and development 239

Learning 239

Training 257

Staff development $\quad 268$

13 Motivation 274

What is meant by motivation? 274

Informal theories of motivation 276

Organizational implications 277

Formal theories of motivation 278

Motivation theories in general 293

Motivation and management 294

14 Attitudes, attitude change and job satisfaction 299

Attitude change $\quad 300$

Attitudes and behaviour $\quad 308$

Attitudes to work: job satisfaction $\quad 314$

15 Leadership 324

Formal theories of leadership $\quad 325$

Leadership and management $\quad 336$

Followership 341

PART IV THE FUTURE OF WORK 345

16 The effects of new technology 347

Technology and work 348

Job design and redesign $\quad 354$

Introducing the new 'new technology' 
x Contents

17 Women at work 368

What is women's work? 369

Organizations and sexuality 379

18 Into the twenty-first century 385

What is likely to change? 386

What is likely to stay the same? 395

Key Studies 402

References 419

Author Index 446

Subject Index 454 


\section{List of figures}

2.1 The 'Russian doll' approach to organizational behaviour 29

2.2 Tall organization (the British Civil Service) 34

3.1 Loudness of normal sounds 45

3.2 Length of line illusions 50

3.3 The vertical-horizontal illusion 51

3.4 The impossible tuning fork 51

3.5 Vase and profiles 52

3.6 Organization of lines 53

3.7 Incomplete figures 53

3.8 Illusion of movement 56

4.1 The multi-layered dimension of time 65

5.1 General stress scale 91

5.2 Occupational stress scale 93

6.1 Brain waves 104

6.2 Psychological splitting 112

6.3 Complementary transactions 119

6.4 Crossed transactions 120

6.5 Neurotic styles 122

7.1 Asch conformity situation 128

7.2 Communication network in five-person groups 134

9.1 The Freudian structure of personality 171

9.2 Summary of formal personality theories 181

9.3 Socialization as illustrated by the Statt Cone 186

10.1 Normal distribution curve 204

10.2 IQ distribution 205

10.3 Sample item from the Minnesota Paper Form Board Test 212

10.4 Sample items from the Bennett Mechanical Comprehension Test 213

10.5 Sample items from the Minnesota Clerical Test 213 
xii List of figures

11.1 Stages in the recruitment and selection process 217

12.1 Distortions of schemas 256

12.2 Stages in the training process 257

13.1 Maslow's hierarchy of needs 279

13.2 Comparison of Maslow and Alderfer models on needs 281

13.3 Classification of needs theorists 283 


\section{List of tables}

4.1 Life stages and the world of work 79

8.1 Transitions into and out of employment 147

9.1 Cattell's 16 personality factors 179

9.2 Reduction to five personality factors 180

9.3 Asch 'warm-cold' study 182

10.1 Vocational personality types 209

10.2 Catalogue of physical and psychomotor abilities 210

15.1 Summary of leadership theories 335

15.2 Mintzberg's managerial roles 337

15.3 Distinguishing between a manager and a leader $\quad 340$

16.1 Mechanistic and organic organizations 358

16.2 Current microelectronics applications 362 


\section{Preface}

When you tell your students that you learn more from them than they do from you, they tend to look at each other and smile. Nevertheless every experienced teacher knows that it's true. This book is the product of what I have learned during the past five years of teaching in the Edinburgh University Management School. My hope is that it might therefore be user-friendly for both teachers and students, with teachers finding the coverage and detail they require and students the level of explanation and writing style.

Each chapter has been designed to stand by itself, so that chapters may be read out of sequence if teachers so desire. At the same time there should be a cumulative learning gain in reading the book all the way through, whether in sequence or not, as familiarity grows (aided by cross-referencing) with the most important themes and ideas.

The book has a psychodynamic orientation, most explicitly set out in Chapter 6: 'The "unconscious" at work', but also informing the discussion of many other areas such as motivation, leadership, mental health, selection, learning and the role of women. The perception of time is also used as a means of integrating a great deal of diverse research. 'The time dimension' is the specific topic of Chapter 4 but it is also used throughout the book as a running motif to help illuminate some familiar material in a rather unusual way.

I would like to thank my publishing editor, Stephen Rutt, for suggesting this book to me. It turned out to be more absorbing and enjoyable to write than I had anticipated! Finally I would like to record a huge debt of gratitude to my wife Judith who not only typed every word of this manuscript but improved it with some tactful editing of my more ill-advised comments and phrasing. The final product is my responsibility alone. 


\section{Acknowledgements}

The author and publishers wish to thank the following for kindly giving permission for the use of copyright material:

Cartoonists and the Writers Syndicate for the Harris cartoon in Chapter 14

HarperCollins for Table 15.2

Jossey-Bass Inc. for Figure 6.5

The Psychological Corporation for Figures 10.3, 10.4 and 10.5

Penguin Books Limited for Figures 6.3 and 6.4

Pergamon Press Limited for Figure 5.1

Tavistock Publications for Table 4.1

Times Newspapers Limited and Professor Cary Cooper for Figure 5.2

John Wiley Inc. for Figures 3.3 and 3.4

Routledge for Figures 2.2 and 9.3

Every effort has been made to trace all copyright-holders, but if any have been inadvertently overlooked the publishers will be pleased to make the necessary arrangement at the first opportunity. 